\title{
Analisis dan Perancangan Sistem Informasi Akuntansi Penjualan dan Persediaan Pada PT XYZ
}

\author{
Martha Viola ${ }^{1}$, Rika Kharlina Ekawati ${ }^{2}$, Trisnadi Wijaya ${ }^{3}$ \\ Akuntansi, STIE Multi Data Palembang \\ Jl. Rajawali No.14, Palembang \\ tataviola21@yahoo.com \\ trisnadiestie-mdp.ac.id \\ Komputerisasi Akuntansi, STMIK GI MDP \\ Jl. Rajawali No.14, Palembang \\ rika@mdp.ac.id
}

\begin{abstract}
Accounting information system is a system that processes data and transactions to generate useful information for planning, controlling and operating a business. Currently there are still companies that have not implemented an accounting information system one of them is PT XYZ. The recording process at this company still uses manual recording which impacts on the unintegrated performance and the level of data and validity that does not run as expected and the needs of the company. The purpose of this research is to analyze and design the accounting information system sales and inventory that runs and identify the needs and requirements of new systems created so as to improve the weaknesses in the system sales and inventory. The research method used is the analysis and design by doing problem analysis in the running system and then design the flowchart and prototyping of the appropriate system to be applied in PT. XYZ. In analyzing the existing procedures, conducted interviews on related parties at PT. XYZ. The results obtained obstacles and problems in the manual system that runs related to the performance and processes that occur mainly in sales and inventory. In this study resulted in an accounting information system design that is adjusted to help the problems faced by PT. $X Y Z$ mainly on sales and inventory recording.
\end{abstract}

Keywords- Analysis, design, accounting information systems, sales, inventory

Intisari- Sistem informasi akuntansi adalah sebuah sistem yang memproses data dan transaksi guna menghasilkan informasi yang bermanfaat untuk merencanakan, mengendalikan dan mengoperasikan bisnis. Saat ini masih ada perusahaan yang belum menerapkan sistem informasi akuntansi, salah satunya yaitu PT XYZ. Proses pencatatan pada perusahaan ini masih menggunakan pencatatan manual yang berdampak pada tidak terintegrasinya kinerja dan tingkat kevalidan data yang tidak berjalan sesuai harapan dan kebutuhan perusahaan. Tujuan dari penelitian ini adalah untuk menganalisis dan merancang sistem informasi akuntansi penjualan dan persediaan yang berjalan serta mengidentifikasi kebutuhan dan persyaratan sistem baru yang dibuat sehingga dapat memperbaiki kelemahan dalam sistem penjualan dan persediaan. Metode penelitian yang digunakan adalah analisis dan perancangan dengan melakukan analisis permasalahan dalam sistem yang berjalan kemudian merancang flowchart dan prototyping dari sistem yang sesuai untuk diterapkan dalam PT. XYZ. Dalam menganalisis prosedur yang ada, dilakukan wawancara pada pihak terkait di PT. XYZ. Hasilnya diperoleh kendala dan permasalahan dalam sistem manual yang berjalan terkait kinerja dan proses yang terjadi terutama dalam penjualan dan persediaan. Dalam penelitian ini menghasilkan suatu rancangan sistem informasi akuntansi yang disesuaikan untuk membantu permasalahan yang dihadapi oleh PT. XYZ terutama pada pencatatan penjualan dan persediaan.

Kata Kunci- Analisis, perancangan, sistem informasi akuntansi, penjualan, persediaan.

\section{Pendahuluan}

Sistem informasi terdiri dari beberapa kategori, seperti Sistem Informasi Akuntansi (SIA), Sistem Informasi Manajemen (SIM) dan sistem informasi lainnya. [1] Saat ini perusahaan memerlukan sistem informasi untuk membantu proses pencatatan transaksi yang ada. Salah satunya adalah penerapan/penggunaan sistem informasi akuntansi.

Menurut Krismiaji [1] sistem informasi akuntansi diperlukan perusahaan karena dalam proses bisnis perusahaan tidak dapat menjalankan seluruh sistem informasi secara bersamaaan seperti sistem informasi eksekutif, pendukung keputusan maupun sistem informasi lainnya, hal ini dikarenakan dampak kemungkinan yang terjadi jika dalam perusahaan belum menerapkan sistem informasi akuntansi adalah laporan akuntansi kurang akurat, kesalahan dalam pencatatan data serta pengulangan data (redundancy data). Adapun keuntungan dan dampak dari pemanfaatan sistem informasi akuntansi belum dirasakan oleh beberapa perusahaan, salah satunya yaitu PT XYZ.

PT. XYZ merupakan salah satu perusahaan yang bergerak di bidang manufaktur bahan kimia dan produk makanan. Saat ini PT XYZ telah mencatat setiap transaksi (penjualan dan persediaan) yang berjalan menggunakan nota transaksi yang kemudian di-input dalam Microsoft Excel untuk digunakan sebagai daftar list pemesanan pelanggan. Penentuan permasalahan dilakukan dengan cara menganalisis prosedur pencatatan sistem informasi akuntansi penjualan dan persediaan yang berjalan dan merancang sistem informasi akuntansi penjualan dan persediaan dalam sebuah perusahaan.

Berdasarkan hasil wawancara dan observasi yang telah dilakukan oleh peneliti pada PT. XYZ diketahui bahwa proses pencatatan yang dilakukan oleh PT. XYZ memiliki beberapa kelemahan, seperti masalah keamanan data yang tidak terkontrol terbukti dengan seringnya kehilangan data transaksi pelanggan, proses pencarian data yang relatif lama karena kesalahan pengisian data, kesalahan pencatatan dalam hal pengurangan dan penambahan stok dikarenakan 
kurangnya keterampilan dalam mengunakan aplikasi Microsoft Excel dan lamanya dalam proses pembuatan laporan akuntansi terbukti dari laporan yang diterima pimpinan selalu mundur dari jadwal yang ditentukan. Pencatatan akuntansi yang tidak terintegrasi ini berdampak kepada kinerja dan tingkat kevalidan data yang tidak berjalan sesuai harapan dan kebutuhan perusahaan. Selain itu juga terjadi penurunan penjualan dengan rentang waktu tahun 2013 - 2015. Hal ini terjadi akibat dari proses transaksi data yang tidak terkontrol dan seringnya terjadi kesalahan dalam pencatatan. Grafik penjualan PT. XYZ yang mengalami penurunan dari tahun 2013 - 2015 dapat dilihat pada Gambar 1.

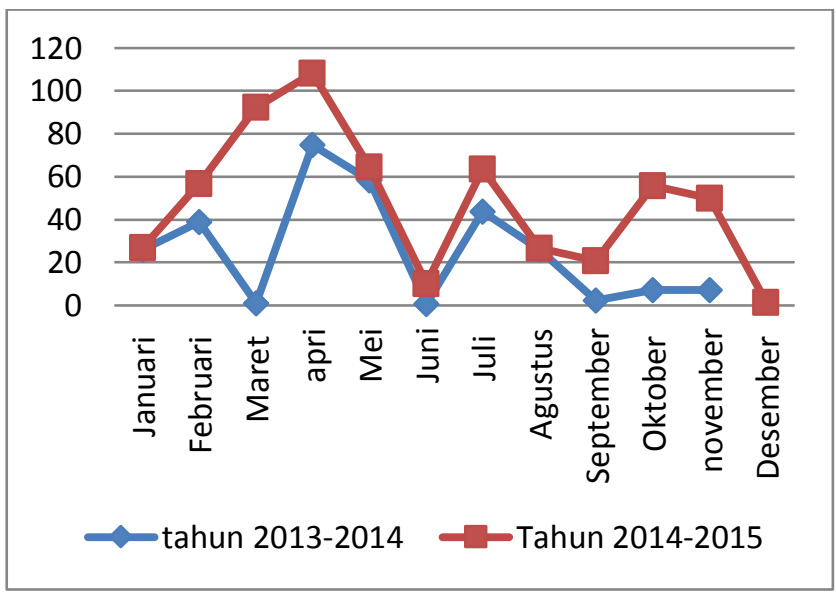

Sumber: PT. XYZ, 2016

Gambar 1. Grafik Penjualan PT. XYZ 2013-2015

Berdasarkan Gambar 1 di atas terlihat adanya penurunan persentase penjualan dari tahun 2013 - 2015. Hal ini terjadi karena penerapan sistem informasi akuntansi yang tidak memadai sehingga ada beberapa transaksi yang tidak tercatat dan kesalahan pencatatan data persediaan yang tidak sesuai dengan gudang yang mengakibatkan laporan penjualan menurun karena kesalahan informasi. Penurunan penjualan tersebut yang mengakibatkan adanya kerugian yang dialami oleh PT. XYZ pada bulan Juni, yaitu 9,51\%, dan yang paling signifikan kerugian terjadi pada bulan Juli yang berkisar pada $19,83 \%$.

Penelitian sebelumnya yang dilakukan oleh Adi [2] pada UMKM Treant Skateshop Semarang menyatakan bahwa sistem informasi akuntansi persediaan barang dagang dapat mempermudah UKM dalam mengolah informasi tentang persediaan barang dagang yang semakin meningkat baik jenis maupun kuantitasnya. Di sisi lain, sistem informasi akuntansi persediaan barang dagang juga diharapkan mampu menghasilkan informasi-informasi yang dibutuhkan oleh perusahaan secara akurat dan cepat. Begitu pula dengan penelitian yang dilakukan oleh Darudianto [3] yang menyimpulkan bahwa sistem informasi akuntansi penjualan kredit dan piutang usaha, dapat mengetahui informasi penjualan melalui laporan penjualan berdasarkan barang, laporan penjualan berdasarkan pelanggan dan dapat membantu manajemen dalam pengambilan keputusan penjualan dan pemberian kredit.

\section{TINJAUAN PUSTAKA}

Tinjauan pustaka dalam penelitian ini menggunakan referensi yang berkaitan dengan penjelasan penjualan, persediaan, sistem informasi akuntansi, sistem informasi akuntansi penjualan, sistem informasi akuntansi persediaan. Seluruh penjelasan di atas menggunakan buku dan penelitian terdahulu sebagai referensi penelitian ini.

\section{A. Sistem Informasi Akuntansi}

Definisi sistem informasi akuntansi (SIA) menurut Hall [4] adalah suatu subsistem yang memproses transaksi keuangan dan non-keuangan yang berpengaruh secara langsung terhadap pemrosesan transaksi keuangan. Dari definisi tersebut dapat disimpulkan bahwa sistem informasi akuntansi adalah suatu sistem yang mengumpulkan dan menginformasikan data keuangan dari setiap transaksi keuangan.

Unsur-unsur yang ada dalam sistem ini, antara lain: [5]

- Orang yang menggunakan sistem.

- Prosedur dan instruksi yang digunakan untuk mengumpulkan, memproses, dan menyimpan data.

- Data mengenai organisasi dan aktivitas bisnisnya.

- Perangkat lunak yang digunakan untuk mengolah data.

- Infrastruktur teknologi informasi meliputi komputer perangkat periferal.

- Pengendalian internal dan pengukuran keamanan yang menyimpan data SIA.

Menurut Romney dan Steinbart [5] sistem informasi akuntansi yang didesain dengan baik, dapat menambah nilai untuk organisasi dengan:

1. Meningkatkan kualitas dan mengurangi biaya produk atau jasa.

2. Meningkatkan efisiensi.

3. Berbagi Pengetahuan.

4. Meningkatkan efisiensi dan efektivitas rantai pasokannya.

5. Meningkatkan struktur pengendalian internal.

6. Meningkatkan pengambilan keputusan.

Adapun tiga fungsi sistem informasi akuntansi adalah sebagai berikut: [1]

1. Mengumpulkan dan memproses data tentang kegiatan organisasi bisnis secara efisien dan efektif.

2. Menghasilkan informasi yang berguna untuk pembuatan keputusan.

3. Melakukan pengawasan yang memadai untuk menjamin bahwa data transaksi bisnis telah dicatat dan diproses secara akurat, serta untuk melindungi data tersebut dan aktiva lain yang dimiliki oleh perusahaan. 


\section{B. Sistem Informasi Akuntansi Penjualan}

Sistem informasi akuntansi penjualan adalah suatu sistem informasi yang mengorganisasikan serangkaian prosedur dan metode yang dirancang untuk menghasilkan, menganalisa, menyebarkan dan memperoleh informasi guna mendukung pengambilan keputusan mengenai penjualan.[6] Dari definisi tersebut dapat disimpulkan bahwa sistem informasi akuntansi penjualan adalah suatu sistem yang dirancang untuk memudahkan pelaku ekonomi dalam mengambil keputusan untuk meningkatkan penjualannya.

Sistem penjualan dibagi menjadi dua sistem, yaitu: [7] 1. Sistem penjualan tunai

Pada sistem ini, bila pembeli sudah memilih barang yang akan dibeli, pembeli diharuskan membayar ke bagian kassa. Oleh karena itu tidak perlu ada prosedur pengiriman barang pada toko penjual. Informasi yang biasa dibutuhkan dalam sistem penjualan tunai, yaitu jumlah penerimaan kas dari penjualan tunai setiap hari dan jumlah kas yang disetorkan ke bank setiap hari.

2. Sistem penjualan kredit

Pada umumnya, sistem penjualan kredit terdiri dari prosedur pesanan penjualan, prosedur persetujuan kredit, prosedur pengiriman barang, prosedur pembuatan faktur dan prosedur akuntansi penjualan kredit. Prosedur pesanan penjualan informasi yang dibutuhkan meliputi pesanan yang belum dapat dipenuhi dan kesanggupan mengirim barang di waktu tertentu.

\section{Sistem Informasi Akuntansi Persediaan}

Sistem informasi akuntansi persediaan adalah sebuah sistem yang memelihara catatan persediaan dan memberi tahu manajer apabila jenis tertentu memerlukan penambahan, dalam perusahaan manufaktur, sistem persediaan mengendalikan tingkat (jumlah) bahan baku dan jumlah produk jadi. [1]

Dari definisi tersebut dapat disimpulkan bahwa sistem informasi akuntansi persediaan adalah suatu sistem yang dibuat untuk mencegah terjadinya pengurangan atau penambahan persediaan barang dan bahan baku secara berlebihan.

Menurut Ristono [8] persediaan dibagi dalam tiga kategori, yaitu :

- Persedian bahan baku dan penolong

- Persedian bahan setengah jadi

- Persediaan bahan jadi

\section{METODOLOGI PENELITIAN}

Pendekatan penelitian yang digunakan dalam penelitian ini adalah pendekatan penelitian kualitatif. Pendekatan kualitatif digunakan untuk mendeskripsikan analisis kondisi dan prosedur yang berjalan di PT. XYZ dan untuk merancang sistem informasi akuntansi, bukan mengarah kepada pengolahan data statistik yang ada di perusahaan.[9]

\section{A. Jenis Data}

Jenis data ada dua macam yang terdiri dari: [9]

1. Data Primer

Sumber primer adalah sumber data yang langsung memberikan data kepada pengumpul data.

\section{Data Sekunder}

Sumber sekunder adalah sumber data yang diperoleh dengan cara membaca, mempelajari dan memahami melalui media lain yang bersumber dari literatur, buku-buku, serta dokumen perusahaan.

Dalam penelitian ini menggunakan jenis data primer yang berupa data wawancara kepada manajemen dan staf di PT. XYZ dan data sekunder yang berupa data perusahaan, yaitu data penjualan, laporan data piutang, dan lain-lain.

\section{B. Teknik Pengumpulan Data}

Teknik pengumpulan data yang dilakukan menggunakan metode wawancara dan observasi, wawancara dilakukan dengan beberapa informan dalam hal ini staff administrasi, staff persediaan dan pelanggan. Sedangkan observasi dilakukan dengan cara mengetahui prosedur sistem yang telah berjalan. berdasarkan wawancara yang dilakukan terdapat beberapa kelemahan dan harapan yang dinginkan perusahaan untuk mengatasi beberapa masalah yang terjadi. Selain itu juga dilakukan analisis dokumen yang ada di dalam perusahaan. Berikut teknik pengumpulan data yang digunakan :

\section{Metode Observasi}

Melakukan peninjauan langsung ke PT. XYZ dengan tujuan untuk mengetahui bagaimana seluruh kegiatan transaksi penjualan dan persediaan yang ada pada PT. XYZ serta proses pembuatan laporan akuntansi secara keseluruhan.

\section{Metode Interview}

Dalam penelitian ini metode interview digunakan untuk menggali data perusahaan baik dari sejarah, profil perusahaan, visi misi perusahaan sampai informasi bagaimana proses transaksi penjualan dan persediaan yang telah dijalankan oleh PT. XYZ saat ini.

\section{Metode Dokumentasi}

Dalam melaksanakan metode dokumentasi, data yang dilihat berupa data-data tertulis yaitu dokumendokumen perusahaan seperti pencatatan transaksi penjualan dan persediaan serta laporan akuntansi secara umum.

\section{Teknik Analisis Data}

Dalam penelitian ini, teknik analisis data yang digunakan adalah analisis data kualitatif dengan merancang sistem informasi akuntansi penjualan dan persediaan pada PT. XYZ

Dari permasalahan yang telah dikemukakan tentang persediaan dan penjualan, maka diambil sejumlah data yang akan dianalisis sesuai kebutuhan dari sistem informasi akuntansi penjualan yaitu data pelanggan, data barang, data penjualan barang, data retur penjualan barang dan data pembayaran. Sedangkan untuk sistem informasi akuntansi persediaan yaitu data stok barang, reminder stock (stok sisa terdikit), data pembelian barang, data supplier, data retur pembelian dan data pembayaran pembelian barang. Hasil analisis akan dirancang dengan menggunakan flowchart, dan prototyping rancangan. 


\section{HASIL DAN PEMBAHASAN}

Dari hasil observasi dan wawancara yang dilakukan pada PT. XYZ dengan melihat konsep serta prosedur yang ada di dalam perusahaan, maka dibuat flowchart yang sesuai dengan proses yang ada kemudian dianalisis permasalahan yang ditemukan.

Masalah yang timbul dalam proses persediaan lebih mengarah kepada pendataan barang yang tidak sesuai dengan fisik barang sehingga terjadi kekeliruan antara pencatatan barang yang ada dengan stok fisik yang tersedia di gudang semua masalah ini diakibatkan oleh beberapa hal antara lain pendataan penjualan dan pembelian yang masih dicatat secara terpisah tanpa adanya monitoring ataupun pengontrolan persediaan yang baik.

Dari segi penjualan diperoleh bahwa pencatatan sistem informasi akuntansi penjualan yang saat ini berjalan belum maksimal hal ini lebih mengarah kepada pencatatan dan perekapan laporan yang dimana sumber data laporan belum terintegrasi secara baik sehingga perekapan pun dilakukan secara satu persatu.

Berdasarkan dari hasil wawancara, adapun dampak yang terjadi dengan sistem informasi akuntansi saat ini adalah :

1. Data yang dicatat dan diproses belum maksimal.

2. Rentan terjadinya kehilangan data.

3. Kesalahan pencatatan dalam hal penambahan dan pengurangan stok.

4. Kinerja yang buruk.

\section{A. Prosedur Persediaan}

Untuk melihat prosedur yang ada dalam PT XYZ disajikan pada Gambar 2 .

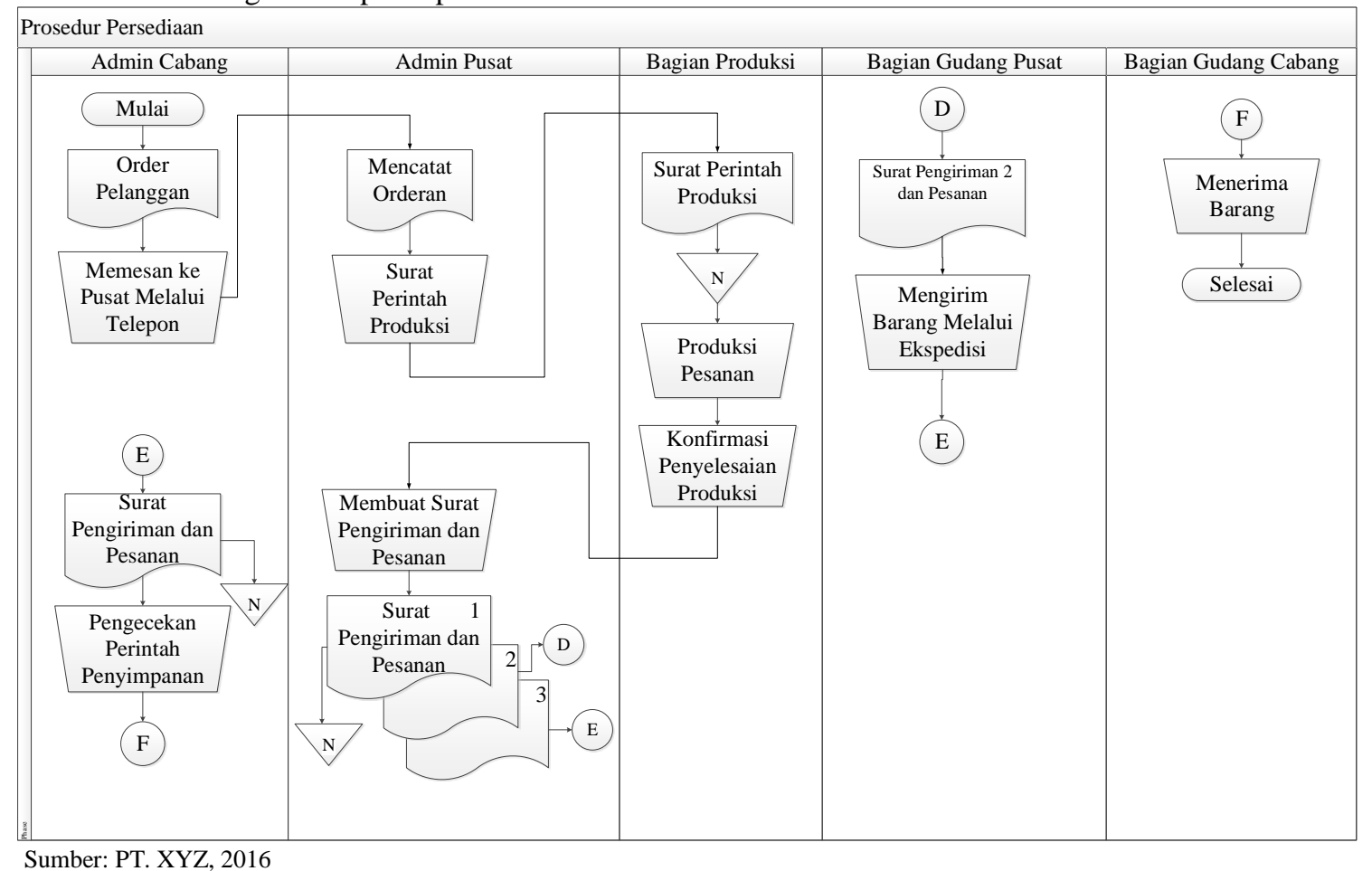

Gambar 2. Flowchart Prosedur Persediaan pada PT. XYZ

Gambar 2 merupakan flowchart prosedur persediaan yang berjalan terdapat masalah dalam hal proses pemesanan barang ke admin pusat. Pemesanan yang dilakukan admin cabang kepada admin pusat masih dilakukan melalui proses telepon dengan melalui media pencatatan manual, memberikan kelemahan berupa kesalahan pencatatan pesanan yang dicatat oleh admin pusat karena keterbatasan informasi yang didapat. Kesalahan pencatatan akan berdampak pada kesalahan dalam proses produksi yang dilakukan bagian produksi yang berdampak pada kerugian biaya produksi dan biaya lainnya.

Selain itu untuk informasi mengenai penyelesaian produksi saat ini belum dapat diketahui oleh admin cabang sehingga informasi pesanan yang diproduksi hanya dapat diketahui ketika barang telah dikirimkan dan sampai ke admin cabang PT. XYZ. Tidak adanya informasi ini membuat pihak administrasi cabang kesulitan untuk memberikan informasi jadwal ketersediaan barang yang dipesan kepada pelanggan, sehingga kualitas layanan perusahaan tidak maksimal.

Adanya alur distribusi dokumen yang banyak ke beberapa bagian seperti bagian gudang, bagian admin cabang maupun admin pusat membuat rentan terjadinya kehilangan dokumen ataupun kesalahan dalam pendistribusian dokumen hal ini justru berdampak kepada proses sumber data pembuatan laporan yang tidak valid. 


\section{B. Prosedur Penjualan}

Prosedur penjualan pada PT. XYZ disajikan dengan flowchart pada Gambar 3. Berdasarkan Gambar 3 terlihat bahwa prosedur penjualan yang berjalan terdapat masalah dalam hal proses pengecekan stok. Prosedur penjualan yang dimulai dari proses pengecekan stok barang membuat proses penjualan membutuhkan waktu yang cukup lama. Hal ini dikarenakan tidak terintegrasinya seluruh data stok dengan data penjualan yang ada di perusahaan sehingga pengecekan stok harus dilakukan secara terpisah. Proses penjualan yang cukup lama akan berdampak kepada layanan kepada pelanggan tidak maksimal. Distribusi dokumen penjualan, seperti memo pesanan pelanggan yang dibuat secara manual juga memberikan kemungkinan adanya kesalahan pencatatan yang membuat informasi yang didapatkan tidak sesuai kebutuhan.

Nota penjualan yang menjadi bukti penjualan merupakan sumber data dalam proses pembuatan laporan masih disimpan secara manual yang kemudian data tersebut baru direkap menjadi sebuah laporan lengkap. Sumber data pembuatan laporan seperti itu akan memberikan kesulitan bagi administrasi untuk menyajikan laporan secara detail, lengkap dengan didukung grafik penjualan maupun grafik lainnya. Laporan yang tidak lengkap akan menyulitkan pimpinan untuk mengambil keputusan berdasarkan hasil evaluasi laporan yang ada

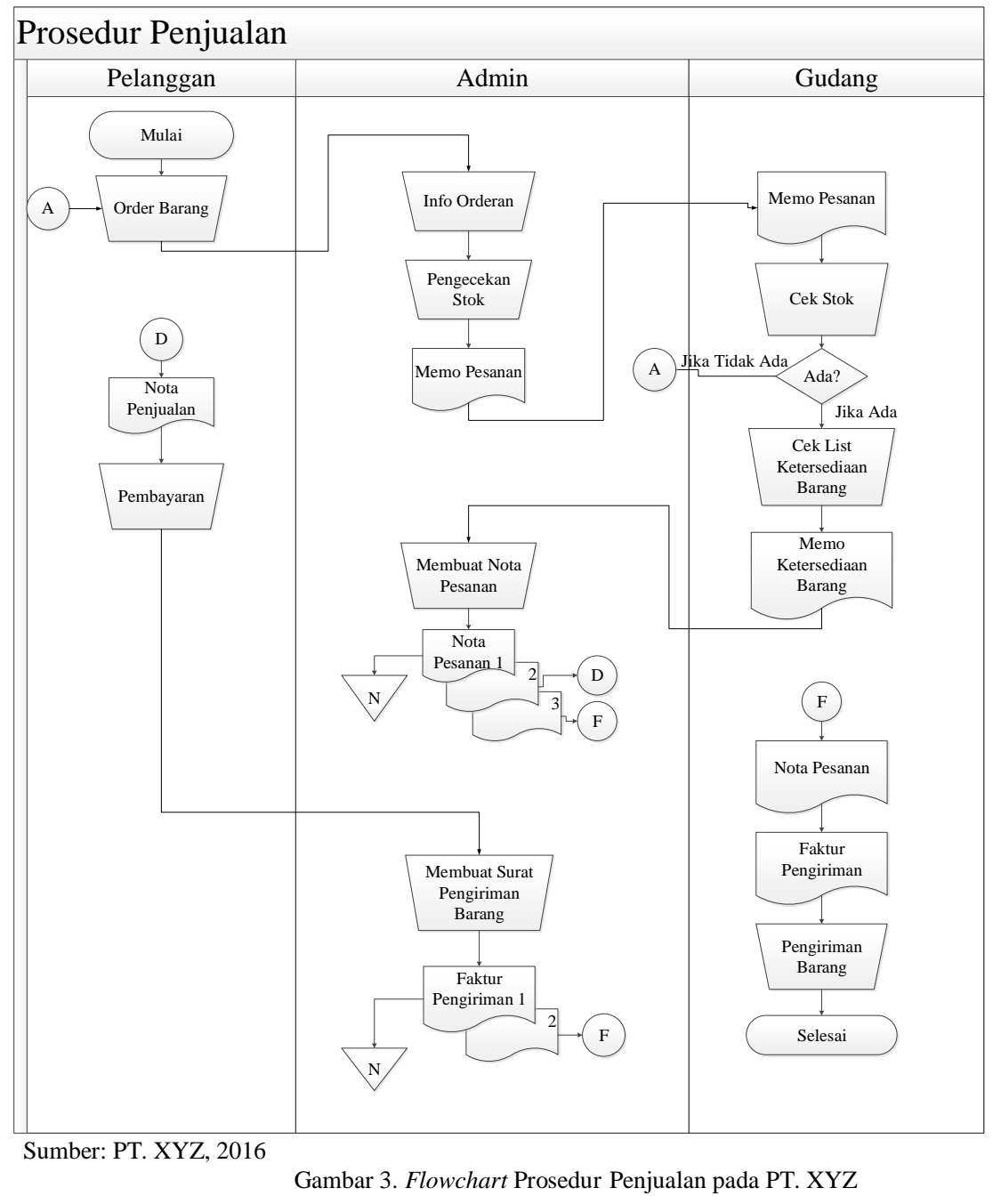

\section{Rancangan Sistem Informasi Akuntansi Persediaan Yang Diusulkan}

Rancangan flowchart yang diusulkan diperlihatkan pada Gambar 4 merupakan hasil rancangan sistem prosedur persediaan. Dapat disimpulkan bahwa sistem yang dirancang menggunakan basis data secara terpusat sehingga siklus akuntansi persediaan dapat dengan mudah diidentifikasi maupun dikelompokan. Selain itu juga distribusi dokumen ke beberapa bagian dapat diminimalisir melalui tampilan data yang tidak harus dicetak sebagai dokumen dalam hal ini hanya berbentuk display data. Informasi stok habis dapat diketahui oleh bagian administrasi tanpa harus menunggu konfirmasi stok habis dari gudang sehingga proses pemesanan barang kepada admin pusat dapat dilakukan secara lebih cepat.

Sumber data yang telah terpusat dalam proses yang diusulkan memberikan kemudahan bagi administrasi dalam hal pembuatan laporan akuntansi persediaan secara lebih akuntabel dan lengkap, hal ini dikarenakan seluruh data transaksi persediaan yang telah berjalan dan disimpan dalam database dapat lebih mudah diakses dan dicari sesuai 
kebutuhan administrasi guna membuat laporan yang dibutuhkan oleh pimpinan.

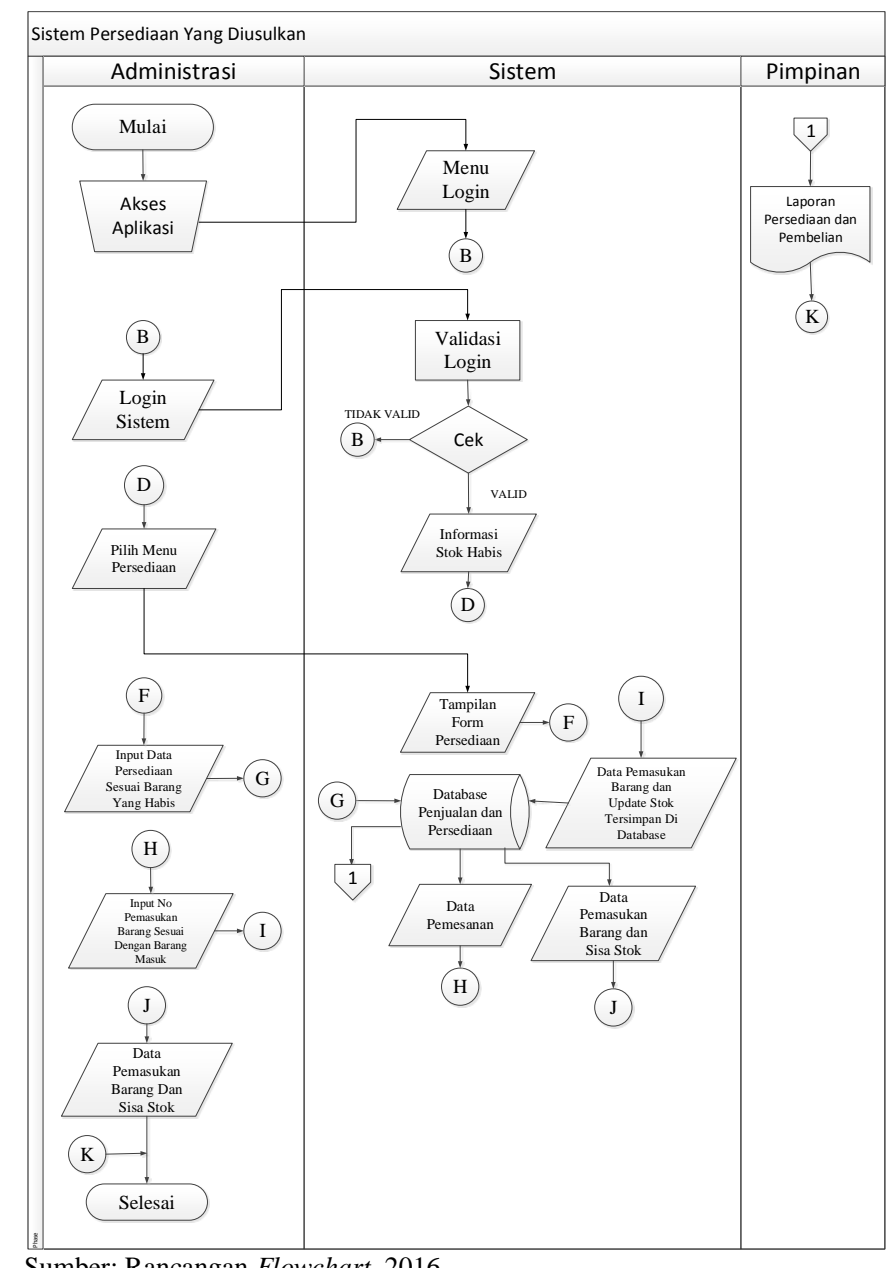

Sumber: Rancangan Flowchart, 2016

Gambar 4. Flowchart Rancangan Sistem Persediaan yang Diusulkan pada PT. XYZ

\section{Rancangan Sistem Informasi Akuntansi Penjualan Yang} Diusulkan

Gambar 5 merupakan hasil rancangan sistem prosedur penjualan di atas dapat disimpulkan sistem yang dirancang menggunakan basis data secara terpusat sehingga siklus akuntansi penjualan dapat dengan mudah diidentifikasi maupun dikelompokan sesuai dengan kebutuhan. Selain itu juga distribusi dokumen ke beberapa bagian dapat diminimalisir melalui tampilan data yang tidak harus dicetak sebagai dokumen dalam hal ini hanya berbentuk display data. Pelanggan yang membeli barang pun akan lebih cepat dilayani tanpa harus menunggu informasi ketersediaan stok dari pihak gudang. Sistem yang diusulkan telah menghubungkan seluruh kegiatan transaksi yang berjalan dengan stok yang tersedia sehingga alur informasi yang ada di administrasi lebih lengkap dan mudah diakses.

Sumber data yang telah terpusat dalam proses yang diusulkan memberikan kemudahan bagi administrasi dalam hal pembuatan laporan akuntansi penjualan secara lebih akuntabel dan lengkap, hal ini dikarenakan seluruh data transaksi penjualan yang telah berjalan dan disimpan dalam database dapat lebih mudah diakses dan dicari sesuai kebutuhan administrasi guna membuat laporan yang dibutuhkan oleh pimpinan. 


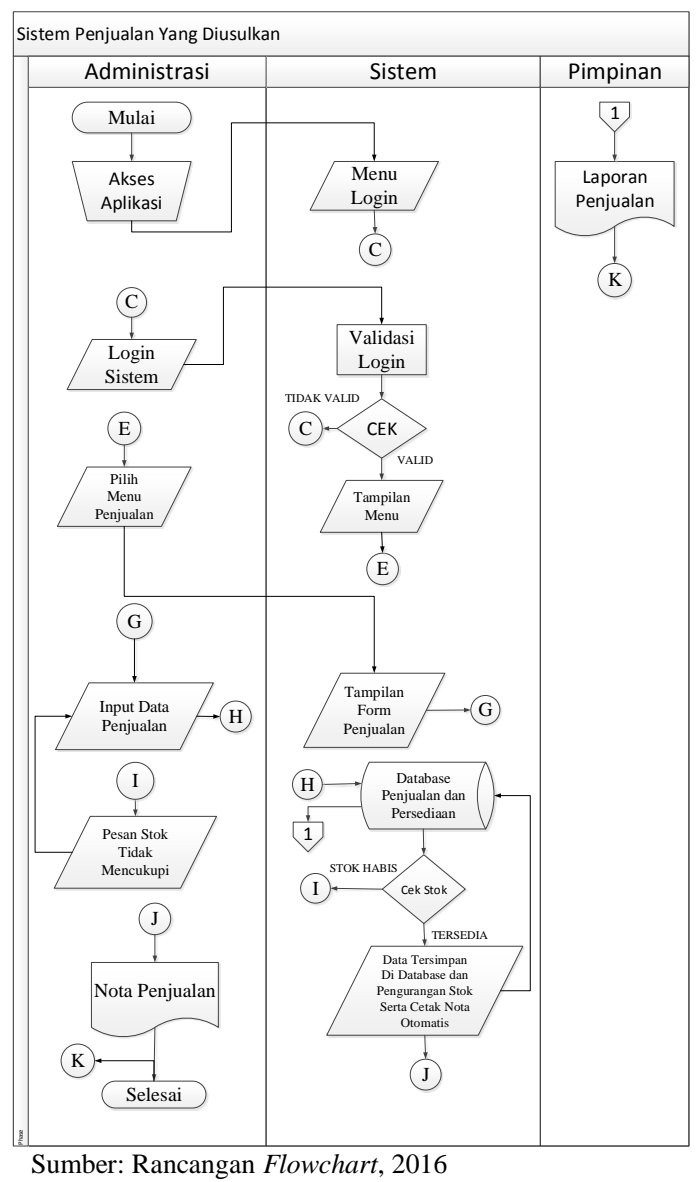

Gambar 5. Flowchart Rancangan Sistem Penjualan yang Diusulkan pada PT. XYZ

\section{E. Design Prototype Rancangan Sistem}

Design prototype ini merupakan rancangan tampilan sistem informasi akuntansi yang sesuai dengan flowchart yang diusulkan, rancangan ini dibuat menggunakan Microsoft Access yang dimana semua field disesuaikan dengan kebutuhan akuntansi perusahaan.

- Rancangan Halaman Login Sistem

Rancangan halaman login digunakan oleh administrasi untuk masuk ke dalam sistem akuntansi.

\section{LOGIN SISTEM}

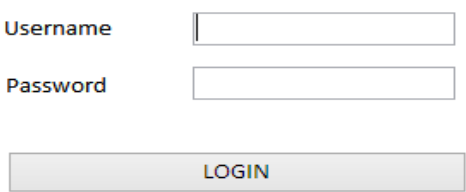

Sumber: Rancangan Prototyping, 2016

Gambar 6. Rancangan Halaman Login Sistem

\section{- Rancangan Halaman Barang}

Rancangan halaman barang digunakan oleh administrasi untuk menginput semua data barang yang dijual oleh perusahaan termasuk di dalamnya data stok barang.

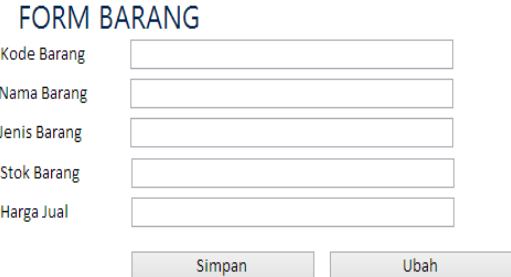

DATA PELANGGAN

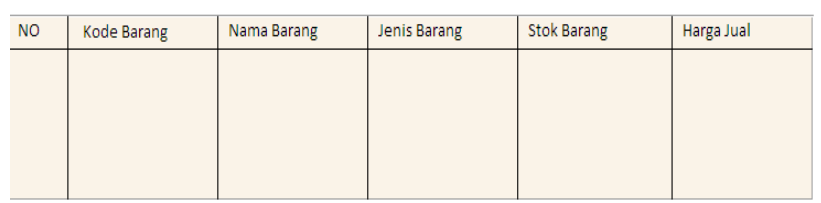

Sumber: Rancangan Prototyping, 2016

Gambar 7. Rancangan Halaman Barang

- Rancangan Halaman Pembelian

Gambar 8 merupakan rancangan halaman pembelian yang digunakan oleh administrasi untuk menginput semua data pembelian kepada perusahaan pusat. 


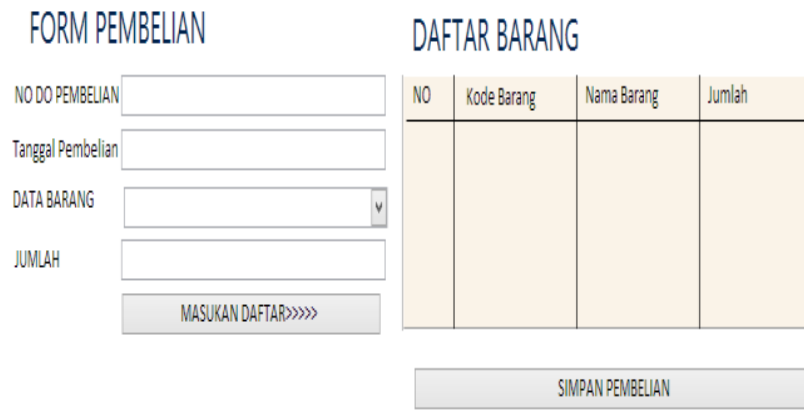

\section{DATA PEMBEELAN}

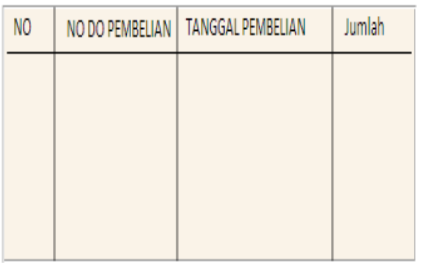

Sumber: Rancangan Prototyping, 2016

Gambar 8. Rancangan Halaman Pembelian

- Rancangan Halaman Penjualan

Gambar 9 merupakan rancangan halaman penjualan yang digunakan oleh administrasi untuk menginput semua data penjualan berdasarkan pembelian pelanggan.

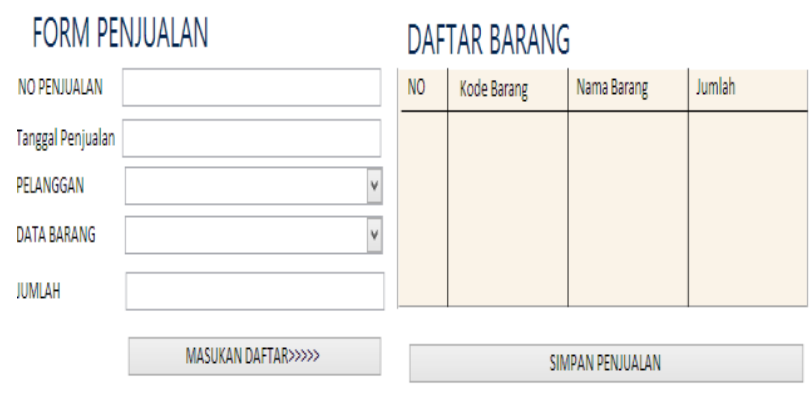

\section{DATA PENJUALAN}

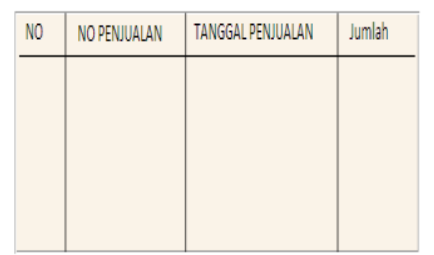

Sumber: Rancangan Prototyping, 2016

Gambar 9. Rancangan Halaman Penjualan

\section{- Rancangan Halaman Input Barang}

Rancangan halaman pemasukan barang digunakan oleh administrasi untuk menginput semua data pemasukan berdasarkan pembelian yang telah dilakukan sebelumnya

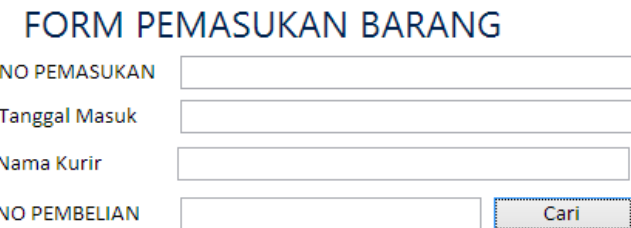

\section{DAFTAR BARANG YANG MASUK}

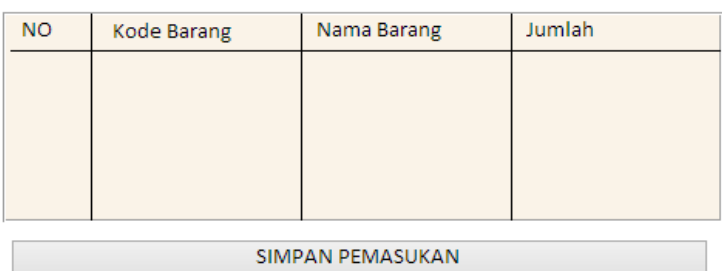

Sumber: Rancangan Prototyping, 2016

\section{Gambar 10. Rancangan Halaman Pemasukan Barang}

- Rancangan Laporan Penjualan dan Pembelian Rancangan halaman laporan penjualan dan pembelian digunakan oleh administrasi untuk merekap semua data transaksi penjualan dan pembelian berdasarkan nomor faktur penjualan dan pembelian dalam satu periode tertentu.

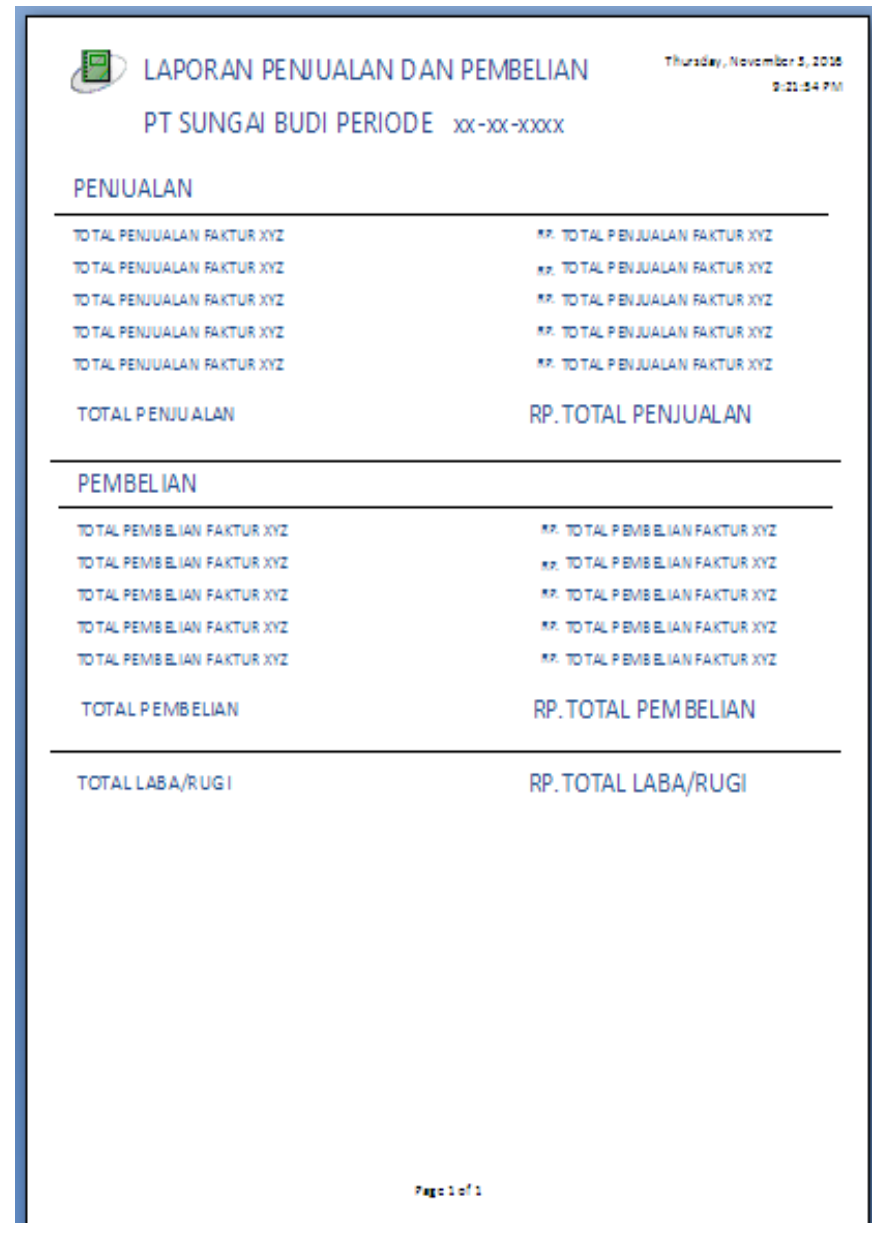

Sumber: Rancangan Prototyping, 2016

Gambar 11. Rancangan Laporan Penjualan dan Pembelian 


\section{F. Pembahasan}

Berdasarkan hasil penelitian yang telah dilakukan dan dibuatnya design prototype rancangan sistem maka prosedur penjualan dan persediaan yang kurang baik dapat terbantu dengan penerapan sistem yang telah dirancang untuk dapat meminimalisir kesalahan sistem serta pencatatan akuntansi penjualan dan persediaan yang ada pada PT. XYZ. Seperti penggunaan login system untuk pengguna untuk pertanggungjawaban transaksi, data barang dan data pelanggan sampai pada laporan pencatatan yang semuanya ter-input dalam sistem. Sehingga proses transaksi dan alur distribusi dokumen yang diterapkan serta pelaporan pada pimpinan dapat tepat waktu dan tepat sasaran dengan data yang akurat.

Kesalahan dalam proses pencatatan akuntansi yang ada saat ini juga seringkali membuat pimpinan perusahaan kesulitan untuk mengontrol dan mengevaluasi hasil transaksi yang telah berjalan sehingga berdampak pada pencapaian target perusahaan yang tidak stabil, hal ini dibuktikan berdasarkan data laporan yang ada pada bulan Juni tahun 2014 nilai penjualan mengalami penurunan sampai ke bulan Juli 2014.

Berdasarkan pernyataan tersebut pencatatan SIA yang telah berjalan dengan hasil penjualan yang didapat masih memiliki kelemahan dalam hal ini ouput ataupun laporan yang dibuat berdasarkan hasil dari pencatatan persediaan dan penjualan tidak dapat dijadikan bahan evaluasi ataupun pendukung keputusan untuk peningkatan penjualan dikarenakan data yang dilaporkan tidak sesuai dengan transaksi dan jumlah barang yang tersedia di gudang. Selain itu, data penjualan juga kurang akurat karena beberapa transaksi yang tidak tercatat, sehingga di laporan terlihat data penjualan yang mengalami penurunan.

\section{- Sistem Informasi Akuntansi Penjualan}

Dalam prosedur penjualan masalah yang dihadapi oleh perusahaan adalah tidak terintegrasinya informasi ketersediaan barang terhadap pencatatan penjualan yang berdampak pada sulitnya mengetahui informasi ketersediaan stok yang diminta. Proses pembuatan laporan yang masih disimpan secara manual memberikan kesulitan bagi administrasi untuk menyajikan laporan secara lengkap sehingga menyulitkan pimpinan untuk mengambil keputusan berdasarkan hasil evaluasi laporan yang ada.

Berdasarkan masalah yang diungkapkan di atas, maka PT. XYZ memerlukan sebuah sistem informasi akuntansi yang telah terintegrasi secara terpusat baik pencatatan penjualan yang mampu menghasikan laporan akuntansi secara lebih lengkap. Selain itu juga dibutuhkan data-data terkait dari dokumen yang dapat diambil dengan mudah oleh pihak yang membutuhkan di dalam perusahaan.

\section{- Sistem Informasi Akuntansi Persediaan}

Informasi yang didapat oleh antar divisi mengenai pemesanan masih rentan mengalami kesalahan karena bersifat manual sehingga membuat adanya kesalahan pesanan yang berdampak kepada kerugian biaya produksi,

Berdasarkan masalah di atas, maka sebaiknya sistem pemesanan dapat dibuat terarah baik dari awal transaksi hingga ke pelaporan akhir yang di-input dalam satu database dengan didukung proses konfirmasi pesanan untuk meminimalkan kesalahan pesanan yang dilakukan.

Berdasarkan penjelasan di atas, maka peran sistem informasi akuntansi penjualan dan persediaan dalam PT. XYZ sangat dibutuhkan untuk mengatasi beberapa masalah yang ada, hal ini senada dengan penelitian sebelumnya yang dilakukan oleh Adi [2], Darudianto [3], dan Ayu [10] yang keseluruhannya menyatakan hasil bahwa sistem informasi akuntansi dalam perusahaan dapat membantu menyelesaikan beberapa masalah baik prosedur penjualan dan persediaan yang ada di perusahaan.

\section{KESIMPULAN}

\section{A. Kesimpulan}

Prosedur penjualan dan persediaan yang saat ini telah berjalan masih kurang baik, hal ini dibuktikan dengan adanya beberapa masalah baik dalam hal pencatatan akuntansi penjualan dan persediaan maupun alur distribusi dokumen yang diterapkan perusahaan. Kesalahan dalam proses pencatatan akuntansi yang ada saat ini juga seringkali membuat pimpinan perusahaan kesulitan untuk mengontrol dan mengevaluasi hasil transaksi yang telah berjalan sehingga berdampak pada pencapaian target perusahaan yang tidak stabil, hal ini dibuktikan berdasarkan data laporan yang ada dari tahun 2013-2015.

Perancangan sistem informasi akuntansi yang dibuat telah disesuaikan dengan kebutuhan PT. XYZ sehingga dapat membantu pencatatan transaksi lebih terstruktur. Dengan menggunakan sistem yang telah dirancang, pencatatan yang ada dapat lebih mudah untuk dikelompokkan dan dicari apabila dibutuhkan serta memberikan kemudahan dalam hal penyajian pelaporan akuntansi dari data pencatatan yang telah dilakukan dan disimpan dalam sebuah basis data.

\section{B. Saran}

Adapun saran yang diberikan kepada perusahaan berdasarkan hasil dari penelitian yang telah dilakukan antara lain :

1. Perusahaan diharapkan dapat menerapkan perancangan yang telah dilakukan agar seluruh pencatatan akuntansi yang ada di perusahaan dapat berjalan lebih maksimal. Serta mengevaluasi pembagian tugas dan wewenang yang lebih baik agar semua transaksi tidak hanya diurusi oleh bagian admin melainkan ada bagian lain yang memiliki kompentensi dan kemampuan sesuai dengan pekerjaan dan pencatatan yang dibutuhkan.

2. Bagi penelitian selanjutnya perancangan yang telah dilakukan dapat diimplementasikan dan 


\section{dikembangkan dengan ruang lingkup yang lebih besar dan kompleks.}

\section{UCAPAN TERIMA KASIH}

Ucapan terima kasih kami berikan pada PT. XYZ yang telah banyak memberikan informasi tentang prosedur dan kendala yang dialami terutama dalam proses penjualan dan persediaan.

\section{DAFTAR PUSTAKA}

[1] Krismiaji (2015), Sistem Informasi Akuntansi, Edisi Keempat, Perusahaan YKPN, Yogyakarta.

[2] Adi, H. H. (2015). Sistem Informasi Akuntansi Persediaan Barang Dagang Pada UMKM Treant Skateshop Semarang Tahun 2015. Skripsi, Fakultas Ekonomi \& Bisnis.

[3] Darudianto, S (2007), Analisis Dan Perancangan Sistem Informasi Akuntansi Pt Maju Bersama (Studi Kasus: Penjualan Dan Piutang Usaha), Skripsi S1, , Dari Www.S3.Amazonaws.Com. [Diakses 01 Agustus 2016]

[4] Hall, Ja (2011), Sistem Informasi Akuntansi, Edisi Keempat, Salemba Empat, Jakarta.

[5] Romney, M Dan Paul John Steinbart 2015, Sistem Informasi Akuntansi, Jagakarsa, Salemba Empat, Jakarta Selatan.

[6] Daud, R, Dkk (2014), Pengembangan Sistem Informasi Akuntansi Penjualan Dan Penerimaan Kas Berbasis Komputer Pada Perusahaan Kecil (Studi Kasus Pada Pt Trust Technologi), Skripsi S1, Www.Eprints.Unsri.Ac.Id [Diakses 02 Agustus 2016]

[7] Wandi, A 2015, Perancangan Sistem Informasi Akuntansi Penjualan Tunai Pada Toko Sumber Sthil, Skripsi S1, Www.Eprints.Dinus.Ac.Id. [Diakses 02 Agustus 2016]

[8] Ristono, A (2009), Manajemen Persediaan, Edisi Pertama, Graha Ilmu, Yogyakarta.

[9] Sugiyono (2013), Metode Penelitian Pendidikan Pendekatan Kuantitatif Kualitatif Dan R\&B, Alfabeta, Bandung.

[10] Ayu Puspa Rengganis, P. (2012). Analisis Dan Perancangan Sistem Informasi Akuntansi Persediaan Barang Dagang Pada OassureSiskem Aneka Indonesia. 